\title{
CORRELATIONS, PATH-COEFFICIENTS AND THE IMPLICA- TION OF DISCRIMINANT FUNCTION FOR SELECTION IN WHEAT (TRITICUM AESTIVUM)
}

\author{
R. S. PARODA* and A. B. JOSHI $\dagger$ \\ Division of Genetics, Indian Agricultural Research Institute, New Delhi
}

Received 10.x.69

\section{INTRODUGTION}

GraIN yield in wheat, as in other crops, is a complex character, the sumtotal of the contributions made by its individual components. Grafius (1959) has even doubted the individuality of grain yield. Yield and some of its components, such as the number of ears per plant, cannot be wholly reliably used as criteria for selection because of their low heritability and wide fluctuations as a result of their interaction with the environment. Thus, to breed for yield, the geneticist has to simplify this complex situation and handle a number of related characters. Grain yield/plant in wheat has a number of components: 1000-grain wt., no. of grains/ear, wt. of grains/ear, and no. of ears/plant. The question as to the extent to which these component characters can effectively be used in selecting for improved yield in wheat is not clear. However, sharply differing views on the effectiveness of the component approach to selective breeding have been presented by Williams (1959, 1960), Grafius (1960), Hayman (1960), and Moll et al., (1962). Further experimental evidence is needed to understand this problem and information is required on: (1) the genetics of grain yield and of the components of yield, (2) genotypic and phenotypic correlation and the direct path of the component characters with yield and the degree of association between the component characters, and (3) the construction of a selection index.

Studies on the genetics of grain yield and on the components of yield have been reported by Wiebel (1956), Whitehouse et al. (1958), Kronstad and Foote (1964) and Paroda (1968). Correlation studies in wheat have been carried out by several workers (Bridgford and Hayes, 1931; Wiebel, 1956; Sikka and Jain, 1958; Gandhi et al., 1964). Information on pathcoefficient analysis as suggested by Wright $(1921,1923)$ and discussed by Dewey and Lu (1959) and several others, which provide a means of untangling the direct and indirect contribution of various factors in building up a complex correlation, is not available in wheat. The basis for the development of discriminant functions in plants has been provided by Smith (1936) using data on wheat and later applied by several workers to a number of crops. Simlote (1947) in durum wheat and Robinson et al. (1951) in corn, obtained gains of nearly 16 per cent. and $9 \cdot 1$ bushels per acre respectively, whereas Panse and Khargonkar (1949) in cotton, Abraham et al. (1954) in rice, Sikka and Jain (1958) and Bhide (1963) in wheat found that the

* Present address: Department of Agricultural Botany, University College of Wales, Aberystwyth.

† Deputy Director General, Indian Council of Agricultural Research, New Delhi. 
selection by the discriminant function method is not superior to the direct selection on yield values.

The objectives of this investigation were:

(1) To investigate genotypic and phenotypic correlations in different generations.

(2) To study direct and indirect effects of component characters on yield, and

(3) To construct a suitable selection index in wheat.

\section{Materials AND METHOdS}

Six parental lines in wheat were selected from the genetic stock at the Indian Agricultural Research Institute and were crossed in a diallel fashion in 1964-65. Agra Local and K.13 were selected as well adapted local varieties. Sonora 64 was included as a recent dwarf introduction from Mexico. N.P.876 was selected as an improved Indian variety with good grain quality. H.26 and H.S.990-483 were included as recently developed strains through hybridisation. Part of the seeds from all 15 single crosses were grown at Wellington (Nilgiris) during the summer of 1965 to obtain $\mathrm{F}_{2}$ seeds.

The experiment in 1965-66 consisted of 6 parental, $15 F_{1}$ and $15 F_{2}$ populations. The layout was a randomised block design comprising 4 replications. Out of a total of 174 rows in each replicate, 4 rows were sown to each parent, 2 rows to each $F_{1}$, and 8 rows to each $F_{2}$ population. The sowing was done by dibbling the seed at a distance of 6 inches in rows 10 feet long, spaced 18 inches apart. Normal cultural practices were followed. Out of 20 plants in each row, observations were recorded on 5 plants selected at random, excluding border plants. The characters scored were: (1) grain yield/plant, (2) 1000-grain wt., (3) no. of grains/ear, (4) wt. of grains/ear, and (5) no. of ears/plant. The mean values for each trait were analysed.

The two variance-covariance matrices necessary for calculating genotypic and phenotypic correlation coefficients and also for evaluating the coefficients $b_{1}, b_{2}, \ldots, b_{n}$, used for the discriminant function technique, were obtained from the mean squares and mean cross products of genotypes and of error for different characters measured in replicated experiment. Analysis of variance for each character and analysis of covariance for all pairs of the 5 characters studied were constructed separately for parental, $F_{1}$ and $F_{2}$ generations. The expectations of mean squares and mean cross products are given as follows:

$\begin{array}{llclcc}\text { Source } & \overbrace{\text { M.S. }}^{\text {Replicates }} & \begin{array}{c}\text { Expectation } \\ \text { of M.S. }\end{array} & & \overbrace{\text { M.C.P. }}^{\text {Analysis of Variance }} & \begin{array}{c}\text { Expectation } \\ \text { of M.G.P. }\end{array} \\ \text { Treatments } & \mathrm{Mr}_{11} & - & \mathrm{Mr}_{12} & - \\ \text { Error } & \mathrm{Me}_{11} & \sigma_{e_{11}}^{2}+r \sigma_{g_{11}}^{2} & \mathrm{Mt}_{12} & \sigma_{e_{12}}^{2}+r \sigma_{g_{12}}^{2} \\ \sigma_{e_{11}}^{2} & \mathrm{Me}_{12} & \sigma_{e_{12}}^{2}\end{array}$

Where $\sigma_{e_{11}}^{2}$ and $\sigma_{g_{11}}^{2}$ are environmental and genotypic variances respectively of character $x_{1}$, 
$\sigma_{e_{12}}^{2}$ and $\sigma_{g_{12}}^{2}$ are environmental and genotypic covariances respectively between characters $x_{1}$ and $x_{2}$, and $r=$ number of replicates.

The genotypic and phenotypic variances $\left(\sigma_{g_{11}}^{2}\right.$ and $\left.\sigma_{p_{11}}^{2}\right)$ and covariances $\left(\sigma_{g_{12}}^{2}\right.$ and $\left.\sigma_{p_{12}}^{2}\right)$ were calculated as follows:

$$
\begin{aligned}
\sigma_{g_{11}}^{2} & =\mathrm{Mt}_{11}-\mathrm{Me}_{11} / \mathrm{r} \\
\sigma_{p_{11}}^{2} & =\sigma_{g_{11}}^{2}+\sigma_{e_{11}}^{2} \text { where } \sigma_{e_{11}}^{2}=\mathrm{Me}_{11} \\
\sigma_{g_{12}}^{2} & =\mathrm{Mt}_{12}-\mathrm{Me}_{12} / \mathrm{r} \\
\sigma_{p_{12}}^{2} & =\sigma_{g_{12}}^{2}+\sigma_{e_{12}}^{2} \text { where } \sigma_{e_{12}}^{2}=\mathrm{Me}_{12}
\end{aligned}
$$

The correlation coefficients were calculated in the usual way.

The path-coefficient analysis was carried out as described by Dewey and $\mathrm{Lu}(1959)$ at the phenotypic level for parental, $F_{1}$ and $F_{2}$ generations separately.

The phenotypic and genotypic variances and covariances obtained from the $F_{2}$ generation were used for constructing discriminant functions using different character combinations according to the procedure given by Smith (1936). The grain yield/plant was also included as one of the independent characters as suggested by Robinson et al. (1951). The expected genetic advance from straight selection (G.A.(S)) and from the discriminant function (G.A.(D)) were calculated as follows:

$$
\text { G.A.(S) }=\frac{z}{p} \frac{g_{y y}}{\sqrt{t_{y y}}} \text { and G.A.(D) }=\frac{z}{p} \sqrt{b_{1} g_{1 y}+b_{2} g_{2 y}+\ldots+b_{n} g_{n y}}
$$

here $\frac{z}{p}$ is the selection differential in standard units, for the present study it was 2.06 for 5 per cent. selected (Lush, 1949). $g_{y y}$ and $t_{y y}$ are the genotypic and phenotypic variances of character $y . b_{1}, b_{2}, \ldots b_{n}$ are the relative weights for each character, and $g_{1}, g_{2 y}, \ldots g_{n y}$ are the genotypic covariances of independent characters with $y$. The expected gain from the discriminant function over straight selection was calculated for all the functions studied, as follows :

$$
\text { Expected gain in per cent. }=\frac{\text { G.A. }(\mathrm{D})}{\text { G.A. }(\mathrm{S})}-1 \times 100
$$

\section{Results}

The genotypic and phenotypic correlation coefficients between all pairs of five characters studied in parental, $F_{1}$ and $F_{2}$ generations separately are presented in table 1. 1000 grain wt. and wt. of grains/ear showed highly significant correlation with grain yield/plant both at the phenotypic and genotypic levels over all generations. The magnitudes were consistent over all generations and were considerably larger at the genotypic level. The correlation between no. of grains/ear and grain yield/plant was positive, but it was significant only in the $F_{1}$ and $F_{2}$ generations-both at the phenotypic and genotypic levels. Low genotypic correlation coefficients in parental and $F_{1}$ generations indicated that the association between these two characters was not very strong.

No. of ears/plant showed a highly significant association with grain 
yield/plant at the phenotypic level in $F_{1}$ and $F_{2}$ generations but it was nonsignificant in the parents. The genotypic association between these two characters was very inconsistent, being negative in the parents and positive in the $\mathrm{F}_{2}$ generation. Further, no. of ears/plant showed very poor or even negative correlation at the phenotypic level with all other component characters studied. However, at the genotypic level, no. of ears/plant showed highly significant negative association in all generations with 1000grain wt., no. of grains/ear and wt. of grains/ear. The genotypic correlation coefficient between no. of ears/plant and no. of grains/ear was not estimated

TABLE 1

Phenotypic (upper right) and genotypic (lower left) correlations between all pairs of 5 traits measured over parental $\left(\mathbf{x}_{1}\right), F_{1}\left(\mathbf{x}_{2}\right)$ and $F_{2}\left(\mathbf{x}_{3}\right)$ generations

\begin{tabular}{|c|c|c|c|c|c|c|}
\hline & & $\begin{array}{l}\text { Grain } \\
\text { yield/ } \\
\text { plant }\end{array}$ & $\begin{array}{l}1000 . \\
\text { grain } \\
\text { wt. }\end{array}$ & $\begin{array}{l}\text { No. of } \\
\text { grains/ } \\
\text { ear }\end{array}$ & $\begin{array}{l}\text { Wt. of } \\
\text { grains/ } \\
\text { ear }\end{array}$ & $\begin{array}{l}\text { No. of } \\
\text { ears/ } \\
\text { plant }\end{array}$ \\
\hline Grain yield/plant & $\begin{array}{l}x_{1} \\
x_{2} \\
x_{3}\end{array}$ & - & $\begin{array}{l}0.536 * \\
0.488 * * \\
0.377 * *\end{array}$ & $\begin{array}{l}0.169 \\
0.374^{* *} \\
0.304^{*}\end{array}$ & $\begin{array}{l}0.597 * \\
0.501 * * \\
0.529 * *\end{array}$ & $\begin{array}{l}0.332 \\
0.697 * * \\
0.522 * *\end{array}$ \\
\hline 1000 -grain wt. & $\begin{array}{l}x_{1} \\
x_{8} \\
x_{3}\end{array}$ & $\begin{array}{l}0.907 * * \\
0.584 * * \\
0.710 * *\end{array}$ & - & $\begin{array}{l}0 \cdot 083 \\
0 \cdot 382^{* *} \\
0 \cdot 173\end{array}$ & $\begin{array}{l}0 \cdot 705^{* *} \\
0 \cdot 747 * * \\
0 \cdot 518 * *\end{array}$ & $\begin{array}{r}-0.182 \\
0.194 \\
-0.078\end{array}$ \\
\hline No. of grains/ear & $\begin{array}{l}x_{1} \\
x_{2} \\
x_{3}\end{array}$ & $\begin{array}{l}0.235 \\
0.355^{*} \\
0.429 * *\end{array}$ & $\begin{array}{c}0.395 \\
-0.308^{*} \\
0.246\end{array}$ & - & $\begin{array}{l}0.570 * \\
0.712 * * \\
0.509 * *\end{array}$ & $\begin{array}{c}-0.065 \\
0.315^{*} \\
0.099\end{array}$ \\
\hline Wt. of grains/ear & $\begin{array}{l}x_{1} \\
x_{2} \\
x_{3}\end{array}$ & $\begin{array}{l}0.889 * * \\
0.846 * * \\
0.649 * *\end{array}$ & $\begin{array}{l}0.922 * * \\
0.953 * * \\
0.837 * *\end{array}$ & $\begin{array}{l}0.704^{* *} \\
-0.014 \\
0.557^{* *}\end{array}$ & - & $\begin{array}{r}-0.186 \\
0.167 \\
0.005\end{array}$ \\
\hline No. of ears/plant & $\begin{array}{l}x_{1} \\
x_{2} \\
x_{3}\end{array}$ & $\begin{array}{l}-0.449 \\
0.054 \\
0.400 * *\end{array}$ & $\begin{array}{l}-0.534 * \\
-0.814 * * \\
-0.247\end{array}$ & $\begin{array}{c}-\overline{162} \\
-0.162 \\
-0.299^{*}\end{array}$ & $\begin{array}{l}-0.773^{* *} \\
-0.699 * * \\
-0.353^{*}\end{array}$ & $\begin{array}{l}- \\
-\end{array}$ \\
\hline
\end{tabular}

* Significant at the 5 per cent. level. ** Significant at the 1 per cent. level.

at parental level because of the high negative covariance between these two characters. 1000-grain wt. showed a highly significant correlation with wt. of grains/ear both at the phenotypic and genotypic levels over all generations. The high values for the genotypic correlations indicated close association between these two component characters. The association between 1000grain wt. and no. of grains/ear was positive and non-significant except in the $\mathrm{F}_{1}$ generation at the phenotypic level. However, these two components were negatively associated at the genotypic level in the $F_{1}$ generation. No. of grains/ear and wt. of grains/ear were highly positively correlated at the phenotypic level in all generations but the genetic association between these two characters was inconsistent.

A path-coefficient analysis, which measures the direct as well as indirect effects of one variable through another on the end-product, was worked out in parental, $F_{1}$ and $F_{2}$ generations at the phenotypic level. The direct and indirect effects of component characters studied on grain yield/plant are presented in table 2 . The positive correlation between grain yield/plant and 1000-grain wt. was the result of the positive direct effect of 1000-grain wt., 
positive indirect effect of wt. of grains/ear and negative indirect effect via no. of grains/ear and no. of ears/plant in all generations. Although the direct positive effect of 1000-grain wt. contributed to a certain extent to its high positive correlation with grain yield/plant, wt. of grains/ear also seemed to have contributed indirectly to this high association. The direct effect of no. of grains/ear on grain yield/plant was negative in parental and $\mathbf{F}_{\mathbf{1}}$

TABLE 2

Path-coefficient analysis of grain yield $\mathrm{v}$ other components of yield for the parental $F_{1}$ and $F_{2}$ generations at the phenotypic level

Grain yield $v$ 1000-grain wt.

Direct effect

Indirect effect via no. of grains/ear

Indirect effect via wt. of grains/ear

Indirect effect via no. of ears/plant

Total

\begin{tabular}{|c|c|c|}
\hline \multicolumn{3}{|c|}{ Path-coefficients } \\
\hline Parents & $F_{1}$ 's & $\mathrm{F}_{2}$ 's \\
\hline $0 \cdot 140$ & 0.084 & $0 \cdot 201$ \\
\hline-0.018 & -0.078 & 0.000 \\
\hline 0.501 & 0.353 & 0.218 \\
\hline-0.087 & $0 \cdot 129$ & -0.042 \\
\hline 0.536 & 0.488 & 0.377 \\
\hline
\end{tabular}

Grain yield $v$ no. of grains/ear

Direct effect

$-0.217$

$-0 \cdot 204$

$0 \cdot 032$

0.001

Indirect effect via 1000-grain wt.

Indirect effect via wt. of grains/ear

$0 \cdot 012$

0.035

Indirect effect via no. of ears/plant

$-0.031$

0.337

$0 \cdot 169$

$0 \cdot 209$

0.215

Total

$0 \cdot 374$

$0 \cdot 053$

0.304

Grain yield $v$ wt. of grains/ear

Direct effect

$0 \cdot 710$

0.473

0.099

0.063

$-0.124$

$-0 \cdot 145$

Indirect effect via no. of grains/ear

$-0.088$

$0 \cdot 111$

Total

0.597

0.501

0.422

$0 \cdot 104$

0.001

0.002

0.529

Grain yield $v$ no. of ears/plant

Direct effect

0.476

0.666

0.536

$-0.025$

0.014

Indirect effect via no. of grains/ear

Indirect effect via wt. of grains/ear

Total

$-0.132$

0.332

0.016

$-0.064$

0.079

$-0.016$

$0 \cdot 000$

0.697

$0 \cdot 002$

0.522

Residual

$0 \cdot 379$

$0 \cdot 299$

$0 \cdot 420$

generations and almost neligible in the $\mathbf{F}_{2}$ generation. Among the component characters, only wt. of grains/ear showed a high positive indirect effect. This indicated that the positive association between no. of grains/ear and grain yield/plant was due to a high positive indirect effect of wt. of grains/ear. The high positive direct effect of wt. of grains/ear revealed that this character itself was responsible for the high degree of association between grain yield and wt. of grains/ear (table 1). In all generations, the indirect effect of 1000-grain wt. was positive but low, whereas no. of grains/ear and no. of ears/plant indicated either very low or negative indirect effects. The partitioning of the correlation between grain yield/plant and no. of ears/plant suggested that the direct effect of no. of ears/plant was high and positive in all the generations studied. The indirect effects, via 1000-grain 
wt., no. of grains/ear and wt. of grains/ear were eigther negative or very slightly positive.

Selection indexes for yield were constructed for the $\mathrm{F}_{2}$ generation (as discussed earlier) and different combinations were examined in an attempt to identify those characters which may be of help during selection. The selection indexes and expected gain in per cent. over straight selection for

TABLE 3

Expected gain in per cent. in grain yield over straight selection from the use of various selection indexes

\begin{tabular}{|c|c|c|c|c|}
\hline Selection index & $b$ value & & & $\begin{array}{c}\text { gain in } \\
\text { per cent. }\end{array}$ \\
\hline 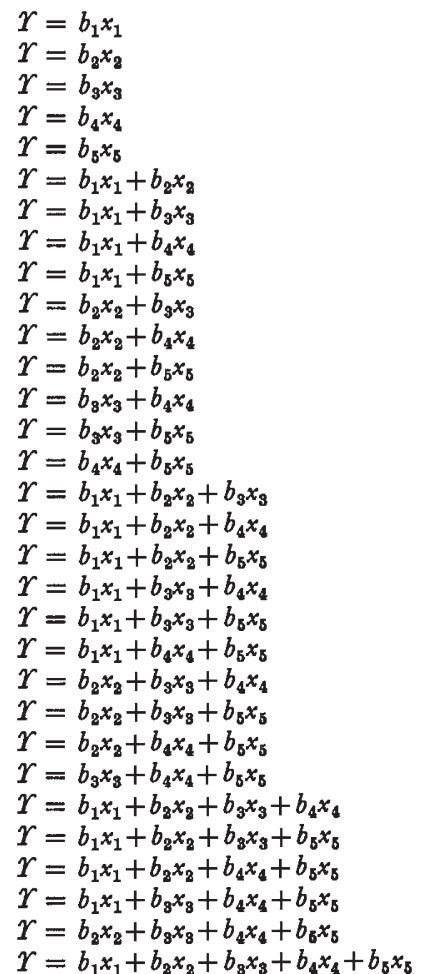 & $\begin{array}{l}0 \cdot 268 \\
0 \cdot 353 \\
0 \cdot 109 \\
3 \cdot 591 \\
0 \cdot 125 \\
0 \cdot 185, \\
0 \cdot 239, \\
0 \cdot 210, \\
0 \cdot 289, \\
0 \cdot 339, \\
0 \cdot 288, \\
0 \cdot 363, \\
-0 \cdot 003, \\
0 \cdot 102, \\
3 \cdot 585, \\
0 \cdot 184, \\
0 \cdot 188, \\
0 \cdot 206, \\
0 \cdot 211, \\
0 \cdot 286, \\
0 \cdot 264, \\
0 \cdot 292, \\
0 \cdot 296, \\
0 \cdot 302, \\
-0 \cdot 014, \\
0 \cdot 187, \\
0 \cdot 206, \\
0 \cdot 217, \\
0 \cdot 264, \\
0 \cdot 304, \\
0 \cdot 216,\end{array}$ & $\begin{array}{r}0 \cdot 242 \\
0 \cdot 017 \\
1 \cdot 278 \\
-0 \cdot 173 \\
0 \cdot 062 \\
1 \cdot 629 \\
0 \cdot 161 \\
3 \cdot 620 \\
0 \cdot 109 \\
0 \cdot 124 \\
0 \cdot 242, \\
0 \cdot 246, \\
0 \cdot 225, \\
-0 \cdot 016, \\
0 \cdot 009, \\
0 \cdot 691, \\
0 \cdot 025, \\
0 \cdot 007, \\
1 \cdot 529, \\
3 \cdot 702, \\
0 \cdot 248, \\
0 \cdot 225, \\
0 \cdot 233, \\
-0 \cdot 006, \\
0 \cdot 013, \\
0 \cdot 235,\end{array}$ & $\begin{array}{l}0.004 \\
-0.151 \\
-0.066 \\
1.405 \\
-0.171 \\
-0.148 \\
1.394 \\
0.148 \\
0 \cdot 154 \\
0 \cdot 126 \\
0.009,-0.237 \\
0.002,-0.065 \\
-0.374,-0.075 \\
0.750,-0.147 \\
1 \cdot 403, \quad 0.152 \\
0.013,-0.497,-0.077\end{array}$ & $\begin{array}{r}4 \cdot 979 \\
-8 \cdot 184 \\
-64 \cdot 563 \\
-28 \cdot 801 \\
-73 \cdot 889 \\
15 \cdot 794 \\
0 \cdot 137 \\
2 \cdot 286 \\
4 \cdot 595 \\
-6 \cdot 073 \\
-4 \cdot 114 \\
-2 \cdot 294 \\
-28 \cdot 795 \\
-57 \cdot 917 \\
-24 \cdot 285 \\
15 \cdot 802 \\
15 \cdot 817 \\
16 \cdot 312 \\
2 \cdot 383 \\
4 \cdot 639 \\
5 \cdot 149 \\
-3 \cdot 862 \\
-5 \cdot 981 \\
1 \cdot 708 \\
-24 \cdot 185 \\
15 \cdot 848 \\
16 \cdot 314 \\
16 \cdot 444 \\
5 \cdot 166 \\
1 \cdot 146 \\
16 \cdot 501\end{array}$ \\
\hline
\end{tabular}

grain yield in each case are given in table 3. The maximum gain of $16 \cdot 50$ per cent. was expected when all the five characters studied were included in the discriminant function. Individually, except grain yield/plant which indicated an expected gain of 4.98 per cent., all of the component characters showed negative gains. When a combination of two or more characters was studied in a function, the expected gains were positive and high only when grain yield/plant was also included as an independent character. The gain of 15.79 per cent. was possible by using a combination of grain yield/plant and 1000-grain wt. No other component character in combination with 
grain yield/plant gave substantial gain. Further, only these combinations showed higher expected gains when grain yield/plant and 1000-grain wt. were also included in the formulae. The gains ranged from 15.79 to 16.50 per cent.

\section{Discussion}

On the basis of the present investigation, the component characters which showed high correlation with grain yield/plant both at the phenotypic and genotypic levels were: 1000-grain wt. and wt. of grains/ear. These two component characters were also highly correlated with each other. The consistently high genotypic and phenotypic correlation coefficients over different generations indicated that these two component characters are genetically associated with grain yield/plant. Moreover, wt. of grains/ear showed a highly positive direct effect on grain yield/plant and no other component character seems to have had any significant indirect effect. 1000 -grain wt. also had a high positive direct effect on grain yield/plant but the high and positive indirect effect via wt. of grains/ear indicated that the high association between these two characters was due to the high indirect effect of wt. of grains/ear. This was a better situation because 1000-grain wt. and wt. of grains/ear were highly correlated at genotypic level. Such high genotypic coefficients in this material could arise by chance as well as by correlated responses to selection arising from linkage and pleiotropy. Separation of these factors require investigations of the variances and covariances among individuals within generations over a number of different generations. In the present investigation, it was not possible to draw conclusions about pleiotropy and linkage because only parental, $F_{1}$ and $F_{2}$ generations were available. Moreover, the chance factor cannot be ruled out unless studies are carried out on a very large sample of lines selected at random. Previous investigations also confirm that grain wt. is highly correlated with grain yield in wheat (Brigford and Hayes, 1931; Weibel, 1956; Sikka and Jain, 1958; Gandhi et al., 1964). Thus, selection on the basis of any of these three characters is expected to give a desired correlated response. The other two component characters, no. of ears/plant and no. of grains/ear showed high phenotypic correlation with grain yield/plant; however their magnitudes were low at the genotypic level and both of these components showed negative association at the genotypic level between themselves as well as with other component characters studied. Although no. of ears/plant showed a high and positive direct effect on grain yield/plant, the utility of this component character was doubtful because of its negative genetic association with grain yield/plant as well as with all other component characters studied. Under these circumstances, it would be desirable to exercise selection for those components which are closely associated at the genotypic level with grain yield/plant and then to compensate for the no. of ears/plant by increasing the plant population/unit area. The situation regarding the no. of grains/ear was also not encouraging because it showed the lowest correlation at the phenotypic level, negative correlation at the genotypic level and a negative direct effect on grain yield/plant. It also appeared to have a negative genetic association with all the other component characters studied and thus, selection on the basis of no. of grains/ear in this wheat material is not likely to be useful for increasing grain yield/plant.

A breeder, in general, is confronted with the problem of selecting a 
character or a number of characters which would give maximum genetic advance through selection. In this endeavour, a number of workers have applied the method of discriminant function in wheat (Simlote, 1947; Sikka and Jain, 1958; Bhide, 1963). Only Simlote observed a gain (of nearly 16 per cent. in durum wheats), whereas the others observed no significant gain in their material. However, the effectiveness of a selection index will depend on the availability of realistic economic weights and accurate variance and covariance estimates (Sprague, 1966). Thus, it is always desirable to estimate accurately the phenotypic and genotypic variances and covariances in each population in order to judge superiority of a discriminant function over straight selection. In this investigation, a maximum gain of 16.5 per cent. could be expected when grain yield/plant and all other component characters studied were included in the formula (table 3 ). This confirmed the previous finding of Simlote (1947) that the application of the discriminant function can lead to an advancement over straight selection in wheat and that the discriminant function method is superior to straight selection. It is essential to realise that most of the previous investigations, including ours, have reported so far the superiority or otherwise of the discriminant function over straight selection on the basis of expected gains. Since observed gains do not always agree with those expected, the claimed advantages of selection indexes need to be confirmed in practice. However, for a breeder, it is very important to know before initiating any selection programme whether or not the discriminant function is superior to straight selection, even on the basis of expected gain, in the material under study. In practice, it is not possible to use as many as five characters for selection programmes and thus one would prefer to use a discriminant function which would lead to maximum possible genetic advance by using a minimum number of characters. With this in view, a number of character combinations were studied and it was possible to obtain an expected gain of 15.79 per cent. by using only grain yield/plant and 1000-grain wt. in the function. No other combination involving one or more component characters, except 1000-grain wt., gave any marked gain when used in the discriminant function along with grain yield/plant. High $b$ values for 1000-grain wt. in all selection indexes which showed gains over 15 per cent. revealed that, during selection, considerably more attention should be given to 1000-grain wt. as compared to grain yield/plant, although both the characters are important from the selection point of view. Previous investigations have indicated that grain yield/plant is genetically a complex trait, whereas 1000-grain wt. is the most heritable and genetically stable component of yield in wheat (Paroda, 1968). In spite of its complex genetic architecture, it was essential to include grain yield/plant in the selection index as all other component characters failed to give positive gains when they were used individually. Thus, selection on the basis of 1000-grain wt., and grain yield/plant would appear to be most effective in improving grain yield in a practical wheat breeding.

\section{Summary}

Studies on genotypic and phenotypic correlations, path-coefficients and discriminant function in wheat show that:

1. 1000-grain wt., and wt. of grains/ear are genetically associated with grain yield/plant, whereas no. of grains/ear and no. of ears/plant are 
negatively associated at the genotypic level with all the characters studied.

2. Path-coefficient analysis revealed a high, direct and positive effect of all component characters except for the no. of grains/ear which showed a negative direct effect. The high positive correlation of 1000-grain wt. and no. of grains/ear with grain yield/plant is due to a high positive indirect effect of wt. of grains/ear.

3. The discriminant function method is superior to straight selection. In the present work a gain of 16.5 per cent. is possible over straight selection by using all the five characters in the function.

4. A considerable gain of 15.79 per cent. is possible by using only grain yield/plant and 1000-grain wt. in the function. Thus, selection on the basis of these two characters, with relatively more emphasis upon 1000-grain wt., would appear to be most effective for the improvement of grain yield in wheat.

Acknowledgments.-We are indebted to Professor S. Ramanujam and Dr N. L. Dhawan for their helpful encouragement and criticism. One of the authors (R. S. P.) thanks the Council of Scientific and Industrial Research of India for the financial support.

Part of a thesis submitted by the senior author in partial fulfilment of the requirements for Ph.D. degree at the Indian Agricultural Research Institute, New Delhi.

\section{RefERENGES}

ABraham, T. P., BUtANy, w. T., AND GHOSh, R. L. M. 1954. Discriminant function for varietal selection in rice. Indian F. Genet. Pl. Breed., 14, 51-53.

BHIDE, v. s. 1963. Discriminant function in wheat hybrid. Indian agric., 7, 76-78.

BRIDGFORD, R. O., AND HAYES, H. K. 1931. Correlation of factors affecting yield in hard red spring wheat. J. Amer. Soc. Agron., 23, 106-117.

DEWEY, D. R., AND LU, K. H. 1959. A correlation and path-coefficient analysis of components of crested wheatgrass seed production. Agron. $7 ., 51,511-518$.

GANDHI, S. M., SANGHI, A. K., NATHAWAT, K. S., AND BHATNAGAR, M. P. 1964. Genotypic variability and correlation coefficients relating to grain yield and a few other quantitative characters in Indian wheats. Indian 7. Genet. Pl. Breed., 24, 1-8.

Grafius, J. E. 1959. Heterosis in barley. Agron. F., 51, 551-554.

GRAFIUS, J. E. 1960. Does overdominance exist for yield in corn? Agron. $7 ., 52,361$.

HAYMAN, B. I. 1960. Heterosis and quantitative inheritance. Heredity, 15, 324-327.

KRONSTAD, W. E., AND FOOTE, W. H. 1964. General and specific combining ability estimates LUSH, J. L. 1949. Animal breeding plans. Iowa State Univ. Press, Ames. in winter wheat (Triticum aestivum vill, Host). Crop. Sci., 4, 616-619.

MOLL, R. H., KOJIMA, H., AND ROBINSON, H. F. 1962. Components of yield and overdominance in corn. Crop Sci., 2, 78-79.

PANSE, v. G., AND KHARGONKAR, s. s. 1949. A discriminant function for selection of yield in cotton. 4th Conf., Indian Cent. Cotton Comm. Bombay.

PARODA, R. s. 1968. Genetic studies on grain weight and other components of yield in wheat (Triticum aestivum L.). Ph.D. Thesis, I.A.R.I., New Delhi.

ROBINSON, H. F., COMSTOCK, F. E., AND HARVEY, P. H. 1951. Genotypic and phenotypic correlations in corn and their implications in selection. Agron. 7., 43, 282-287.

SIKKA, S. M., AND JAIN, K. B. L. 1958. Correlation studies and the application of discriminant function in aestivum wheats for varietal selection under rainfed condition. Indian 7 . Genet. Pl. Breed., 18, 178-186.

SIMLOTE, K. M. 1947. An application of discriminant function for selection of durum wheats. Indian J. agric. Sci., 17, 269-280.

sMith, H. F. 1936. A discriminant function for plant selection. Ann. Eugen., 7, 240-250.

sPRAGUE, G. F. 1966. Quantitative genetics in plant improvement. In Kenneth J. Frey (ed.). Plant Breeding. Iowa State Univ. Press, Ames. Pp. 315-347.

Whitehouse, R. N. H., THOMPSON, J. B., AND DO VAlLE RIBEIRO, M. A. M. 1958. Studies on the breeding of self-pollinated cereals. 2. The use of a diallel cross analysis in yield prediction. Euphytica, 7, 147-169. 
WIEBEL, D. E. 1956. Inheritance of quantitative characters in wheat. Iowa St Coll. F. Sci., $30,450-451$.

WILliams, w. 1959. Heterosis and the genetics of complex characters. Nature, 184, 527-530. WILLIAMs, w. 1960. Heterosis and the genetics of complex characters. Heredity, 15, 327-328. WRIGHT, s. 1921. Correlation and causation. F. agric. Res., 20, 557-585.

WRIOHT, s. 1923. The theory of path-coefficients-a reply to Niles criticism. Genetics, 8, $239-255$. 